\title{
ANALISIS PERILAKU KOMPLAIN KONSUMEN ONLINE SHOPPING
}

\author{
Nasyiatul Aisyiyah $^{\left.{ }^{*}\right)}$, Hartoyo ${ }^{1}$, Diah Krisnatuti ${ }^{2}$ \\ ${ }^{1}$ Sekolah Bisnis, Institut Pertanian Bogor, Bogor 16151, Indonesia \\ ${ }^{2}$ Departemen Ilmu Keluarga dan Konsumen, Fakultas Ekologi Manusia, Institut Pertanian Bogor,
} Bogor 16680, Indonesia

${ }^{*}$ E-mail: nasyia92@gmail.com

\begin{abstract}
Abstrak
Bisnis online memiliki peranan kuat dalam memenuhi kebutuhan konsumen saat ini, namun bisnis ini masih memiliki keterbatasan yang mengakibatkan tingginya jumlah komplain yang dilakukan konsumen. Penelitian ini bertujuan untuk menganalisis pengaruh dari kualitas produk dan layanan online terhadap perilaku komplain konsumen yang dikaitkan juga dengan aspek kepribadian konsumen. Studi ini menggunakan desain penelitian cross sectional dengan survey online. Responden adalah mahasiswa berusia 17-22 tahun yang dipilih secara purposive sampling berdasarkan kriteria memiliki pengalaman ketidakpuasan dalam belanja online satu tahun terakhir dengan jumlah 161 responden. Data dianalisis secara deskriptif dan menggunakan SEM (Structural Equation Modelling) dengan perangkat lunak Smart-PLS. Hasil menunjukkan bahwa perilaku komplain yang ditunjukkan dengan ketidakpuasan konsumen disebabkan oleh produk cacat, delivery time, dan kesalahan pengiriman produk. Kategori fashion dan kosmetik memiliki tingkat ketidakpuasan tertinggi. Konsumen belanja online mempunyai cara merespon ketidakpuasan yang bermacam-macam diantaranya passive (34,0\%), voicer $(40,0 \%)$, iratest $(25,0 \%)$, dan activist $(1,0 \%)$. Perilaku komplain konsumen dipengaruhi secara positif signifikan oleh kualitas produk dan layanan serta kepribadian. Hasil tersebut menegaskan bahwa peningkatan tingkat kecacatan produk dan layanan yang dirasakan konsumen menyebabkan peningkatan tingkat komplain yang akan dilakukan oleh konsumen. Selanjutnya karakteristik kepribadian konsumen tipe extraversion dan openness to experience lebih cenderung menjadi pengeluh jika terjadi kesalahan dalam proses konsumsi produk/jasa.
\end{abstract}

Kata kunci: belanja online, ketidakpuasan, komplain, perilaku konsumen, persepsi kualitas

\section{Complaint Behavior Analysis of Online Shopping Customer}

\begin{abstract}
Online business has a strong role to meet consumer need but this business still has limitation so cause increasing of complaint behavior. This study aims to analyze the influence of the quality of online product and service on consumer complaint behavior and its relation with consumer's personality. The study used cross sectional desaign with online survey. Respondents were 161 college student of 17-22 years old and chosen by purposive sampling based on the criteria of having experienced dissatisfaction in online shopping in the past year. Data were analyzed descriptively and SEM (Structural Equation Modelling) with Smart-PLS software. The result show that consumer dissatisfaction is caused by product defect, delivery time, and product deliver failed. Fashion and cosmetic categories have the highest level of dissatisfaction. Online shopping consumers have various ways to respond to dissatisfaction including passive (34.0\%), (voicer $40.0 \%)$, iratest $(25.0 \%)$, and activists $(1.0 \%)$. Consumer complaint behavior is positively and significantly influenced by perceived quality (product and service) and personality. It means that the higher level of defect in product and service perceived by customers, the higher level of complains that consumers will make. Furthermore, consumer personality characteristics of extraversion and openness to experience are more likely to complaint if there is an error in product or service.
\end{abstract}

Keywords: complaint, customer behavior, dissatisfaction, online shopping, perceived quality

\section{PENDAHULUAN}

Bisnis online menjadi salah satu cara memromosikan dan menjual barang melalui internet yang mulai sering dilakukan pelaku usaha. Pembelian online pun juga semakin marak dilakukan konsumen. Kondisi ini ditunjukkan dengan meningkatnya penjualan e-commerce hingga 144 triliun pada tahun
2018. Perilaku belanja online paling banyak dilakukan oleh konsumen berusia 19-34 tahun yang juga merupakan konsumen tertinggi dalam pemanfaatan internet (APJII, 2017). Perilaku belanja melalui toko online mulai sering dilakukan konsumen meskipun memiliki berbagai kekurangan dan kendala, salah satunya adalah tingginya keraguan konsumen dengan proporsi 40,6 persen (Daily socialid, 2016). Selain itu, beberapa permasalahan lain 
dari sisi layanan maupun produk yang ditimbulkan dari belanja online ditunjukkan pada beberapa hal meliputi waktu pengiriman barang, konfirmasi pembayaran, kesalahan pengiriman produk, dan produk cacat (Daily socialid, 2016). Permasalahan lain yaitu kurangnya keamanan, tidak adanya pemeriksaan fisik produk, kurangnya informasi, dan tampilan visual menjadi penyebab utama ketidakpuasan konsumen online (Quareshi, 2015). Beberapa faktor lain yang berdampak pada tingkat kepuasan konsumen dan minat beli adalah layanan pelanggan, pengiriman, dan sistem pelacakan pascapembelian (Cao, Haya, \& Paul, 2017). Beberapa kasus tersebut menimbulkan berbagai dampak pada konsumen, salah satunya peningkatan komplain pada tahun 2017 mencapai 16 persen pada belanja online (APJII, 2017).

Ketidakpuasan konsumen biasanya ditunjukkan dalam bentuk perilaku komplain. Perilaku komplain didefinisikan sebagai semua kemungkinan pendapat atas ketidakpuasan yang dirasakan pada saat pembelian, selama proses konsumsi maupun selama memiliki barang tersebut (Crie, 2003). Teori perilaku komplain merupakan salah satu disiplin ilmu pada perilaku konsumen pascapembelian yang terjadi setelah evalusi konsumsi produk dan jasa yang dapat mengindikasikan pada loyalitas maupun perilaku ketidakpuasan yang ditunjukkan dengan komplain (Zeithaml, Bitner, \& Gremler, 2009). Perilaku komplain memiliki pengaruh tidak hanya bagi persepsi pelanggan pada produk, tetapi memengaruhi pelanggan lain seperti keluarga dan teman (Tronvoll, 2008). Selain itu Ndubisi dan Ling (2006) menggambarkan jika perilaku komplain dapat menyebabkan kehilangan pelanggan dan untuk mempertahankan pelanggan yang loyal dapat mengurangi biaya daripada harus menarik pelanggan baru.

Kepuasan atau ketidakpuasan merupakan perasaan senang atau kecewa yang timbul karena membandingkan kinerja produk yang dipersepsikan terhadap ekspektasi dan dapat menjadi indikasi terjadinya pembelian ulang saat konsumen memiliki persepsi positif dan apabila tidak puas akan menimbulkan kekecewaan yang justru mengakibatkan hilangnya pelanggan (Kotler \& Keller, 2009). Kepuasan dapat dipengaruhi oleh kualitas produk (product quality) maupun kualitas layanan (service quality), harga, situasi, maupun kepribadian konsumen (Zeithaml et al., 2009; Simanjuntak \& Hamimi, 2019). Perceived product quality didefinisikan sebagai kondisi aktual produk secara fungsional, konsistensi antara kualitas spesifikasi, dan kondisi nyata produk online (Ahn, Ryu \& Han, 2004). Perceived product quality berbentuk atribut produk, harga, sifat kepentingan produk, dan tingkat kerusakan yang dapat memengaruhi kepuasan konsumen dan berdampak pada evalusi pascapembelian dalam bentuk komplain (Donoghue \& Klerk, 2006). Berdasarkan kualitas produk dan layanan yang diterima konsumen akan memersepsikan perasaan yang berbeda, seperti tingkat harga dapat memengaruhi perilaku komplain akibat dari ketidakpuasan (Kim, Lee, \& Mattila, 2014). Konsumen rasional cenderung melakukan komplain dengan melihat situasi dan tingkat kerusakan produk. Dengan tingkat kecacatan produk yang lebih tinggi, konsumen akan lebih mempertimbangkan untuk melakukan komplain (Thogersen, Juhl, \& Poulsen, 2009).

Selain itu menurut Ahn et al. (2004) kualitas layanan juga memengaruhi penerimaan produk online oleh konsumen. Kualitas layanan merupakan bagian penting dalam bisnis online dikarenakan pelaku bisnis harus menyediakan layanan online untuk pencarian, memesan, dan mengirim produk. Layanan online adalah kepuasan pelanggan yang dapat dikelola dan dikontrol dengan pelayanan yang diberikan pada konsumen (Malik, 2012). Pengalaman yang menyenangkan dalam belanja online dapat dipenuhi dengan memerhatikan beberapa hal seperti efisiensi desain situs web, ketersediaan sistem, pemenuhan, keamanan, dan layanan konsumen dalam setiap transaksi (Shergil \& Chen, 2005). Kualitas layanan berbasis internet (e-service quality) yang memberikan layanan informasi konsumen dan memberikan kemudahan dalam mengakses website akan mempercepat setiap transaksi serta menyingkat pencarian barang (Shafiee \& Bazargan, 2017). Faktor lain yang memengaruhi ketidakpuasan adalah nilai yang dipersepsikan (perceived value) yang berarti usaha konsumen dalam membandingkan produk atau jasa dari perusahaan tertentu dengan pesaingnya ditinjau dari manfaat, kualitas, dan harga (Krisno \& Samuel, 2013). Nilai yang dirasakan mampu menciptakan peluang untuk membandingkan kinerja perusahaan dan dapat menimbulkan dampak positif pada kepuasan pelanggan (Bayraktar, Tatoglu, Turkyilmaz, Delen, \& Zaim, 2012).

Perilaku konsumen yang berbeda-beda dalam menghadapi ketidakpuasaan dikarenakan batas ukur toleransi konsumen berbeda 
sehingga respon yang dilakukan akan berbeda pula. Respon konsumen belanja offline menunjukkan perilaku komplain dengan tindakan pengeluh dalam bentuk tindakan irates, voicer dan activist (Prasetya, Hartoyo, \& Tinaprila, 2016; Kim \& Boo, 2011). Cho, II, Roxanne, dan Jerry (2002) mengemukakan konsumen belanja offline lebih cenderung komplain atas ketidakpuasan. Temuan tersebut berbeda dengan hasil penelitian Putri (2014) yang menemukan perilaku tidak komplain (no action) sebagai perilaku terbanyak dalam pengunaan jasa eduecotourism. Kajian selanjutnya menemukan faktor yang menyebabkan perbedaan tersebut. Perbedaan tindakan complain konsumen ditemukan tergantung dengan kepribadian konsumen. Phau dan Sari (2004) menunjukkan konsumen yang memiliki kepribadian dengan tipe kepercayaan tinggi dan individualis akan cenderung melakukan komplain saat terjadi kesalahan. Berry (2013) menyatakan bahwa individu dengan kendali diri yang lebih baik akan menyukai menggunakan saluran komplain secara langsung begitu juga pada individu dengan kepribadian sociability yang tinggi.

Perbaikan kecil dan tidak efektif dapat menyebabkan ketidakpuasan berulang pada pelanggan sehingga pelaku bisnis online perlu memiliki strategi service recovery untuk menyelesaikan masalah dari kegagalan produk. Service recovery memiliki peranan penting dalam meningkatkan kepuasan dan loyalitas konsumen yang ditunjukkan dengan memberikan respon ketika terjadi sesuatu yang salah pada pelanggan (Davidow, 2000). Hal tersebut memberikan dampak positif terhadap hubungan antara perusahaan dengan pelanggan serta meningkatkan kepuasan dan kepercayaan yang diberikan oleh perusahaan.

Penelitian sebelumnya telah menemukan bahwa perilaku komplain berhubungan dengan beberapa faktor diantaranya atribut produk, demografi, dan sifat produk (Prasetya et al., 2016; Donoghue \& Klerk, 2006; Halstead \& Droge, 1991); kualitas layanan berdasarkan serqual dan sistem informasi (Putri, 2014; Cho et al., 2002); nilai dan level ketidakpuasan (Hwang \& Zhao, 2010; Ramadhani, 2014); serta kepribadian, situasi, dan sikap (Thogersen et al., 2009). Respon dari ketidakpuasan pada penelitian sebelumnya terdiri atas private complaint, public complaint, no complaint, active complaint, maupun passive complaint (Tronvoll, 2008; Putri, 2014).
Penelitian yang dilakukan ini berbeda dengan penelitian sebelumnya yang tidak menekankan pada salah satu produk maupun jenis toko online maupun jasa seperti toko offline, restoran, rumah sakit, maupun tempat wisata educotourism. Selain itu, kebaruan dari penelitian ini adalah penggabungan beberapa variabel yang sebelumnya diteliti. Penelitian sebelumnya hanya menggunakan variabel service quality dengan dimensi serqual (Putri, 2014), personality dengan dimensi extraversion, openness to experience dan conscientiousness (Ekinci, Calderon, \& Siala 2016); sementara pada penelitian ini dilakukan penggabungan variabel tersebut dengan memerhatikan juga faktor yang memengaruhi kepuasan lainnya seperti perceive value dan product quality (Zeithaml et al., 2009). Berdasarkan kajian yang dilakukan maka urgensi penelitian ini adalah memberikan masukan secara teoritis. Selain itu, diharapkan dengan memahami perilaku komplain dapat memberikan perlindungan konsumen dan memberikan masukan bagi pelaku bisnis online dalam hal penanganan komplain. Penelitian ini menekankan pada faktor perceived product quality, perceived service quality, perceived value dan faktor personality pada belanja online. Tujuan dari studi ini adalah untuk mengidentifikasi permasalahan ketidakpuasan konsumen saat transaksi online, menganalisis perilaku complain dalam belanja online, dan menganalisis faktor yang memengaruhi perilaku komplain dalam belanja online.

\section{METODE}

Desain penelitan ini menggunakan desain studi kuantitatif dan cross sectional study yang dilakukan di salah satu sekolah di Institut Pertanian Bogor. Pengumpulan data dari responden dilakukan menggunakan self administered survey dengan kuesioner online yang bersifat open close-ended questionnaire. Populasi dalam penelitian ini adalah mahasiswa sarjana yang pernah belanja online di salah satu toko online, e-commerce maupun marketplace. Teknik pengambilan contoh menggunakan purposive sampling dengan kriteria mahasiswa yang pernah mengalami ketidakpuasan dalam satu tahun terakhir dengan jumlah 161 responden.

Variabel penelitian terdiri atas eksogen dan endogen yang terdiri atas 28 indikator. Variabel eksogen terdiri atas perceived product quality yang merujuk pada keseluruhan persepsi atas kualitas secara fungsional dari produk sebenarnya, konsistensi 
antara spesifikasi kualitas produk online, dan kualitas nyata secara fisik (Ahn et al., 2004). Pengukuran perceived product quality terdiri atas indikator kualitas, warna, fitur, reliability, durability, dan kesesuaian dengan mengacu pada instrumen penelitian Aaker (1997) dan Ahn et al. (2004). Pengukuran variabel perceived product menggunakan delapan pernyataan indikator dengan nilai Cronbach's alpha 0,88 . Variabel perceived service quality adalah keseluruhan persepsi konsumen atas kualitas layanan yang dirasakan dalam melakukan belanja produk maupun jasa yang meliputi efisiensi, pemenuhan, dan interaktivitas dengan mengacu pada instrumen penelitian Zeithaml et al. (2009). Pengukuran variabel perceived service menggunakan sepuluh pernyataan dengan nilai Cronbach's alpha 0,89 . Variabel perceived value adalah keseluruhan penilaian konsumen terhadao produk yang dikonsumsi berdasarkan persepsi yang dimiliki dengan mengacu instrumen pada penelitian Sweeney dan Soutar (2001). Variabel perceived value diukur dengan tiga pernyataan dengan nilai Cronbach's alpha 0,73 . Selanjutnya, variabel personality adalah karakteristik individu yang ditunjukkan akibat dari interaksi dengan lingkungan yang digambarkan oleh tiga dimensi yaitu extraversion, openness to experience, dan conscientiousness dengan mengacu pada instrumen penelitian Ekinci et al. (2016). Dimensi extraversion, openness to experience, dan conscientiousness masing-masing diukur dengan tiga pernyataan yang memiliki nilai Cronbach's alpha 0,76, 0,79 dan 0,74. Sementara itu, variabel endogen adalah perilaku komplain konsumen yang dilakukan responden terkait kerugian pembelian yang dialami. Perilaku komplain terbagi menjadi empat tipe konsumen pengeluh yaitu tipe passive, voicer, iratest, dan activist dengan mengacu pada instrumen penelitian Zeithmal, Bitner dan Gremler (2009) dengan nilai Cronbach's alpha 0,72.

Pengambilan data dilakukan dengan menyebarkan tautan/link kuesioner online dalam bentuk google doc dan disebarkan pada media sosial seperti Whatapps dan Line atau melalui pesan langsung pada mahasiswa yang menjadi kerangka contoh. Kuesioner terdiri atas tiga bagian, bagian pertama berisi pertanyaan mengenai pengalaman belanja online, pertanyaan mengenai kategori produk yang mengecewakan, dan tindakan komplain akibat dari ketidakpuasan. Tindakan komplain terdiri atas delapan pertanyaan yang dikategorikan menjadi empat yaitu passive, voicer, irates dan activist. Bagian kedua merupakan pertanyaan mengenai karakteristik sosiodemografi dan perilaku konsumen dalam belanja online seperti jenis kelamin, uang saku, rata-rata pengeluaran belanja online setiap transaksi, dan karakteristik penggunaan internet. Bagian ketiga terdiri atas pertanyaan mengenai variable penelitian (perceived product quality, perceived service quality, perceived value, dan kepribadian). Skala data penelitian menggunakan skala Likert satu sampai dengan lima, dengan kategori sangat tidak setuju sampai dengan sangat setuju. Skor satu menunjukkan sangat tidak setuju, skor dua tidak setuju, skor tiga netral, skor empat setuju, dan skor lima sangat setuju. Proses input dan seleksi data dilakukan setelah pengumpulan data dengan menggunakan Microsoft Excel yang kemudian dianalisis menggunakan metode SEM (Structural Equation Modelling) melalui program Smart-PLS.

Analisis yang dilakukan diantaranya uji reliabilitas dan validitas, analisis deskriptif dan analisis inferensia menggunakan SEM (Structural Equation Modelling). Analisis deskriptif digunakan untuk melihat persentase gambaran mengenai karakteristik dan perilaku responden meliputi jenis kelamin, pendapatan dalam bentuk uang saku per bulan, dan intensitas penggunaan internet. Analisis inferensia yang dilakukan dengan menguji pengaruh variabel perceived product quality, perceived service quality, perceived value dan kepribadian terhadap perilaku komplain.

Hipotesis dalam penelitian ini adalah:

H1 : Persepsi konsumen terhadap kualitas produk (perceived product quality) berpengaruh nyata terhadap perilaku komplain konsumen

$\mathrm{H} 2$ : Persepsi konsumen terhadap kualitas layanan (perceived service quality) berpengaruh nyata terhadap perilaku komplain konsumen

H3 : Persepsi konsumen terhadap nilai produk (perceived value) berpengaruh nyata terhadap perilaku komplain konsumen

H4 : Kepribadian (personality) berpengaruh nyata terhadap perilaku komplain konsumen

\section{HASIL}

\section{Tipe Perilaku Komplain Konsumen}

Passive. Tipe ini biasanya menunjukkan tindakan yang paling mudah dilakukan oleh konsumen karena tidak melibatkan tindakan 
apapun untuk mengatasi permasalahan belanja. Hasil kajian memperlihatkan bahwa responden cenderung untuk diam tanpa menunjukkan ketidakpuasannya apabila terjadi kesalahan produk yang diterima. Hal tersebut dibuktikan bahwa sekitar tiga dari sepuluh responden $(34,0 \%)$ menyatakan memilih tindakan passive (Gambar 1).

Voicer. Temuan lain menunjukkan bahwa proporsi terbesar mahasiswa yang menjadi responden mengambil tindakan voicer dalam menghadapi ketidakpuasannya, yaitu sebesar 40,0 persen. Hasil tersebut mengindikasikan bahwa empat dari sepuluh responden mengambil tindakan dengan cara menyampaikan langsung kesalahan yang terjadi kepada penjual yang bersangkutan. Tipe responden voicer lebih dominan dibandingkan dengan tipe komplain yang lain dalam penelitian ini.

Irates. Hasil penelitian menunjukkan bahwa satu dari empat responden $(25,0 \%)$ melakukan komplain. Bentuk komplain tersebut berupa penyampaian melalui media sosial (Medsos) terkait pernyataan negatif mengenai ketidakpuasan yang dirasakan. Selain itu, perilaku irates yang dilakukan responden dalam penelitian ini ialah berupa menyarankan keluarga dan teman untuk tidak menggunakan produk tersebut.

Activist. Tipe komplain konsumen yang terakhir adalah activist. Konsumen yang terkategori ke dalam tipe ini ialah mereka yang melakukan pengaduan ketidakpuasan pada lembaga perlindungan konsumen maupun badan hukum untuk menyelesaikan permasalahan ketidakpuasannya. Hasil penelitian menunjukkan, responden yang tergolong pada tipe komplain tergolong kecil yaitu hanya $1,0 \%$.

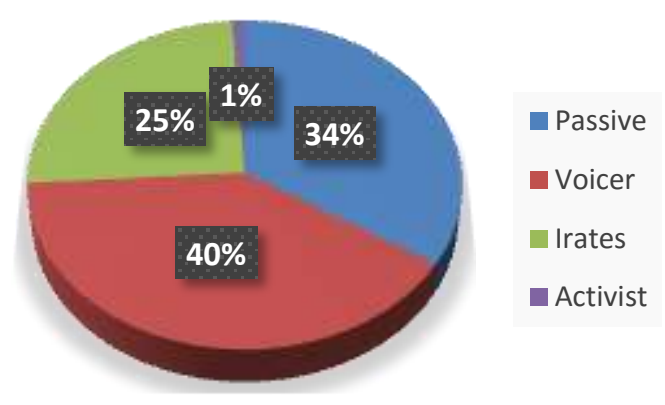

Gambar 1 Sebaran konsumen berdasarkan tipe perilaku komplain

\section{Pemetaan Perilaku Komplain berdasarkan Karakteristik Konsumen}

Pemetaan perilaku komplain berdasarkan karakteristik jenis kelamin dan perilaku belanja konsumen dapat memberikan informasi mengenai hubungan jenis kelamin, kondisi keuangan, dan harga produk dengan perilaku komplain. Hasil penelitian menunjukkan bahwa rentang usia responden 17-22 tahun dengan rata-rata usia 20 tahun. Responden perempuan $(66,0 \%)$ lebih banyak dibandingkan dengan responden laki-laki $(34,0 \%)$. Tabel 1 menunjukkan bahwa responden perempuan lebih menunjukkan perilaku komplain voicer dan irates sedangkan responden laki-laki lebih rendah persentasenya pada perilaku tersebut. Responden perempuan lebih mengekpresikan ketidakpuasan kepada penjual dan menyampaikan pengalamannya kepada keluarga atau teman dan pada media sosial.

Penelitian menemukan bahwa lebih dari setengah responden $(59,0 \%)$ mempunyai uang saku dengan rentang 1-2 juta rupiah per bulan. Perilaku komplain pada belanja online juga terlihat hubungannya dengan jumlah uang saku yang diterima responden. Hasil pada Tabel 1 menunjukkan bahwa responden dengan uang saku di bawah 1 juta rupiah menunjukkan perilaku passive, dalam arti tidak melakukan apapun saat terjadi kesalahan produk maupun layanan. Dalam Tabel 1 juga menunjukkan adanya kecenderungan bahwa semakin meningkatnya jumlah uang saku akan semakin meningkat perilaku komplain konsumen. Responden dengan dengan rentang uang saku 2-4 juta akan cenderung melakukan komplain dalam bentuk voicer dan irates, artinya saat terjadi kesalahan maka akan mengambil tindakan langsung kepada penjual maupun menyampaikan pengalamannya kepada keluarga, teman maupun media sosial.

Perilaku komplain pada belanja online juga terlihat kaitannya dengan perilaku penggunaan internet dan intensitas kunjungan pada situs online, serta perilaku konsumsi produk online. Sebagian besar responden menggunakan internet 9 jam per hari $(62,0 \%)$. Penelitian ini juga menemukan bahwa sebagian besar responden memiliki intensitas penelusuran toko online 1- 5 jam per minggu. Hal ini menunjukkan bahwa responden memiliki minat tinggi dalam belanja online. Responden menghabiskan 1-2 jam untuk menyelesaikan setiap transaksi pada belanja online dan waktu tersebut dinyatakan efisien. Responden 
memiliki minat tinggi jika terdapat beberapa fasilitas yang ditawarkan seperti adanya diskon, voucher, gratis pengiriman, dan promo chasback setiap pembelian. Dalam penelitian dilakukan pemetaan perilaku komplain berdasarkan penggunaan internet untuk menganalisis lebih jauh pemahaman responden mengenai teknologi informasi dan kesadaran keberadaan situs belanja online. Frekuensi responden dari 1- 5 jam per minggu hingga lebih dari 9 jam per hari memperlihatkan kecenderungan perilaku komplain voicer, iratest, dan activist. Hasil penelitian menunjukkan tidak adanya perbedaan yang nyata pada tingkat intensitas responden. Namun dapat disimpulkan bahwa responden yang lebih lama menggunakan internet untuk menunjang kegiatannya $(60,0 \%)$ akan melakukan komplain saat terjadi kesalahan dalam belanja online yaitu dengan tipe komplain voicer dan iratest.

Perilaku konsumen pada belanja online digambarkan oleh rata-rata pengeluaran setiap transaksi belanja yang digunakan untuk melihat perilaku dalam minat atau daya beli konsumen pada produk online. Sebagian besar responden mengeluarkan kurang dari Rp250.000,00 untuk membeli setiap produk $(54,0 \%)$ dan juga dalam rentang Rp250.000,00-500.000,00 (40,0\%). Kategori produk yang sering dibeli oleh konsumen berupa fashion seperti baju, jaket, scarf, aksesoris; dan kategori kosmetik seperti skin care. Hasil menunjukkan bahwa responden menganggap belanja fashion lebih murah pada situs online dan rentang pengeluaran yang paling besar proporsinya sesuai dengan kondisi keuangan responden yang merupakan mahasiswa sarjana. Tabel 1 menggambarkan konsumen belanja online menunjukkan produk dengan harga rendah di bawah Rp100.000,00 akan cenderung lebih passive $(42,0 \%)$, artinya konsumen hanya diam dalam menghadapi ketidakpuasan. Hal lain ditunjukkan berbeda saat produk yang dibeli lebih mahal. Jika harga produk lebih dari Rp100.000,00 menunjukkan perilaku voicer. Hal ini juga berlaku pada harga produk yang lebih tinggi. Hasil tersebut menunjukkan bahwa semakin mahal produk yang dibeli secara online maka akan memengaruhi sikap konsumen dalam bertindak khususnya untuk lebih bertindak vocal menyampaikan complain (voicer) atau melakukan komplain kepada penjual secara langsung

Berdasarkan hasil studi ketidakpuasan konsumen juga dilihat dari kategori produk yang menyebabkan ketidakpuasan dari pembelian sebelumnya. Penelitian ini menemukan bahwa kategori produk yang sering dianggap menyebabkan tidak puas yaitu pada kategori produk fashion $(53,0 \%)$, produk elektronik $(21,0 \%)$, dan produk kosmetik dan skin care (13,0\%). Berdasarkan pendapat tersebut responden menyatakan penyebab dari ketidakpuasan akibat dari produk cacat, delivery time, kesalahan pengiriman, dan produk tidak sesuai dengan deskripsi dan layanan penjual. Jika dipetakan perilaku komplain berdasarkan kategori produk yang dibeli konsumen maka dapat digambarkan bahwa konsumen belanja online memiliki kecenderungan bertipe pengeluh voicer atau melakukan komplain pada penjual utamanya pada kategori produk fashion $(36,0 \%)$. Sementara itu, untuk konsumen dengan kategori produk kosmetik $(43,0 \%)$ dan elektronik $(53,0 \%)$ lebih pada tipe konsumen yang irates atau melakukan WOM (Words of Mouth) kepada orang lain dengan cara langsung atau melalui media sosial. Pada tipe activist dapat dilihat kategori fashion lebih mendominasi untuk melakukan komplain saat terjadi kesalahan. Tabel 1 memperlihatkan bahwa semua produk yang dibeli oleh konsumen dan terjadi kesalahan maka dapat memberikan dampak yang berbeda, sesuai dengan tipe produk yang dibeli. Produk kosmetik dan elektronik dapat memberikan dampak yang lebih tinggi pada konsumen dengan melakukan negatif WOM pada konsumen lain. Hal ini dapat disebabkan bahwa kosmetik terkait erat dengan isu kesehatan sedangkan produk elektronik merupakan produk dengan harga yang lebih tinggi sehingga konsumen akan menyampaikan pengalaman negatifnya kepada orang lain guna memberikan informasi bahwa produk tersebut memiliki kualitas rendah.

Perilaku komplain ditunjukkan dengan periode ketidakpuasan konsumen dalam satu hingga lima bulan terakhir. Responden menyatakan bahwa ketidakpuasan banyak terjadi pada situs e-commerce dibandingkan marketplace dan toko personal online di media sosial. Media sosial berkontribusi dalam ketidakpuasan konsumen $(20,0 \%)$, hal ini dikarenakan, kondisi real produk dan tampilan foto yang terpajang dalam toko online di media sosial yang tidak sesuai. Persentase terendah pada marketplace responden menyatakan bahwa jika produk terorganisir dengan baik dan memiliki customer service untuk membantu setiap transaksi. 
Tabel 1 Pemetaan karakteristik responden berdasarkan jenis perilaku komplain

\begin{tabular}{|c|c|c|c|c|c|c|c|c|}
\hline \multirow{2}{*}{ Variabel } & \multicolumn{2}{|c|}{ Passive } & \multicolumn{2}{|c|}{ Voicer } & \multicolumn{2}{|c|}{ Irates } & \multicolumn{2}{|c|}{ Activist } \\
\hline & (n) & $(\%)$ & (n) & (\%) & (n) & $(\%)$ & (n) & (\%) \\
\hline \multicolumn{9}{|l|}{ Jenis kelamin } \\
\hline Laki-laki & 20 & 36,4 & 23 & 41,8 & 11 & 20,0 & 1 & 1,8 \\
\hline Perempuan & 35 & 33,0 & 42 & 39,6 & 29 & 27,4 & 0 & 0,0 \\
\hline \multicolumn{9}{|l|}{$\begin{array}{l}\text { Penggunaan internet } \\
\text { (jam/hari) }\end{array}$} \\
\hline $1-5$ & 1 & 20,0 & 2 & 40,0 & 2 & 40,0 & 0 & 0,0 \\
\hline $1-4$ & 7 & 35,0 & 6 & 30,0 & 7 & 35,0 & 0 & 0,0 \\
\hline $5-8$ & 12 & 33,3 & 14 & 38,9 & 10 & 27,8 & 0 & 0,0 \\
\hline$\geq 9$ & 35 & 35,0 & 43 & 43,0 & 21 & 21,0 & 1 & 1,0 \\
\hline \multicolumn{9}{|l|}{ Uang saku (juta/bulan) } \\
\hline$\leq 1$ & 12 & 46,1 & 8 & 30,8 & 6 & 23,1 & 0 & 0,0 \\
\hline $1-2$ & 32 & 33,7 & 40 & 42,1 & 22 & 23,2 & 1 & 1,0 \\
\hline $2-3$ & 9 & 29,0 & 13 & 42,0 & 9 & 29,0 & 0 & 0,0 \\
\hline $3-4$ & 2 & 22,2 & 4 & 44,5 & 3 & 33,3 & 0 & 0,0 \\
\hline \multicolumn{9}{|l|}{ Harga produk (Rupiah) } \\
\hline$\leq 100.000$ & 29 & 42,0 & 25 & 36,2 & 15 & 21,8 & 0 & 0 \\
\hline $101.000-250.000$ & 17 & 28,8 & 23 & 39,0 & 19 & 32,2 & 0 & 0 \\
\hline $251.000-500.000$ & 6 & 23,1 & 13 & 50,0 & 6 & 23,1 & 1 & 3,8 \\
\hline $501,000-1$ juta & 3 & 75,0 & 0 & 0,0 & 1 & 25,0 & 0 & 0,0 \\
\hline$\geq 1$ juta & 0 & 0,0 & 3 & 100,0 & 0 & 0,0 & 0 & 0,0 \\
\hline \multicolumn{9}{|l|}{ Kategori produk } \\
\hline Fashion & 32 & 36,0 & 31 & 34,8 & 26 & 29,2 & 0 & 0,0 \\
\hline Kosmetik & 7 & 33,3 & 9 & 42,9 & 5 & 23,8 & 0 & 0,0 \\
\hline Elektronik & 8 & 23,5 & 18 & 53,0 & 7 & 20,6 & 1 & 2,9 \\
\hline Lainnya & 8 & 47,1 & 7 & 41,2 & 2 & 11,7 & 0 & 0,0 \\
\hline
\end{tabular}

Estimasi Validitas dan Reliabilitas

Evaluasi model dilakukan untuk memrediksi dan menguji hubungan prediktif antarkonstruk serta hubungan konstruk dan indikatornya. Evaluasi model SEM PLS dilakukan dengan cara mengevaluasi model pengukuran dan evaluasi model struktural. Evaluasi model pengukuran dan model struktural dapat dilihat pada Tabel 2 Hasil analisis menunjukkan bahwa variabel yang digunakan telah valid karena memiliki nilai AVE lebih dari 0,5. Selain itu, semua indikator yang digunakan telah memiliki loading factor lebih dari 0,5 (Hair, Black, Babin, Anderson, \& Tarham, 2006); telah memenuhi nilai Cronbach's alpha lebih dari 0,6 dan nilai composite reliability lebih dari 0,7 (Latan \& Ghozali, 2012). Oleh karenanya, variabel-variabel yang digunakan dalam penelitian ini telah memenuhi rule of thumb dan dapat dinyatakan variabel yang digunakan reliabel.

\section{Pengujian Hipotesis}

Parameter yang digunakan untuk evaluasi struktural adalah dengan pengujian nilai $\mathrm{R}$ square. Nilai R-square perilaku komplain adalah 0,32 . Hal ini menunjukkan bahwa perilaku komplain dapat dijelaskan oleh semua variabel hanya sebesar 32 persen sedangkan sisanya dipengaruhi oleh variabel lainnya yang tidak terdapat pada penelian ini seperti faktor motivasi konsumen, faktor kemungkinan komplain yang dilakukan konsumen diterima oleh toko online, dan faktor sikap konsumen terhadap komplain. Selain itu evaluasi goodness of fit secara keseluruhan dapat dilakukan dengan menggunakan kriteria GoF yang disebut GoF index (Latan \& Ghozali, 2012).

Tabel 2 Realiability estimate

\begin{tabular}{|c|c|c|c|}
\hline Variabel & $\begin{array}{c}\text { Cronbach's } \\
\text { Alpha }\end{array}$ & $\begin{array}{l}\text { Composite } \\
\text { Reliability }\end{array}$ & $\begin{array}{c}\text { Average } \\
\text { Variance } \\
\text { Extracted } \\
(A V E)\end{array}$ \\
\hline $\begin{array}{l}\text { Complaint } \\
\text { behavior }\end{array}$ & 0,60 & 0,83 & 0,71 \\
\hline $\begin{array}{l}\text { Conscientiou } \\
\text { sness }\end{array}$ & 0,64 & 0,81 & 0,58 \\
\hline Extraversion & 0,73 & 0,85 & 0,65 \\
\hline $\begin{array}{l}\text { Opennes to } \\
\text { Experience }\end{array}$ & 0,78 & 0,89 & 0,81 \\
\hline $\begin{array}{l}\text { Perceived } \\
\text { Product }\end{array}$ & 0,87 & 0,89 & 0,54 \\
\hline $\begin{array}{l}\text { Perceived } \\
\text { service }\end{array}$ & 0,86 & 0,89 & 0,55 \\
\hline $\begin{array}{l}\text { Perceived } \\
\text { value }\end{array}$ & 0,72 & 0,83 & 0,62 \\
\hline
\end{tabular}


Table 3 Hasil Pengujian Hipotesis model SEM

\begin{tabular}{|c|c|c|c|c|c|}
\hline Jalur & & $\mathrm{DE}$ & TE & Ket & $\begin{array}{l}\mathrm{T}- \\
\text { stat }\end{array}$ \\
\hline $\begin{array}{l}\text { Perceived } \\
\text { Product } \\
\text { Complaint } \\
\text { behavior }\end{array}$ & $->$ & $0,149^{* *}$ & $0,149^{\star *}$ & $\begin{array}{r}\text { Terima } \\
\mathrm{H} 1\end{array}$ & 2,05 \\
\hline $\begin{array}{l}\text { Perceived } \\
\text { service } \\
\text { Complaint } \\
\text { behavior }\end{array}$ & $->$ & $0,231^{* *}$ & $0,231^{* *}$ & $\begin{array}{r}\text { Terima } \\
\mathrm{H} 2\end{array}$ & 3,14 \\
\hline $\begin{array}{l}\text { Perceived } \\
\text { value } \\
\text { Complaint } \\
\text { behavior }\end{array}$ & $->$ & $-0,071$ & $-0,071$ & $\begin{array}{r}\text { Tolak } \\
\text { H3 }\end{array}$ & 0,57 \\
\hline $\begin{array}{l}\text { Personality } \\
\text { Complaint } \\
\text { behavior }\end{array}$ & $->$ & $0,159^{* *}$ & $0,159^{* *}$ & $\begin{array}{r}\text { Terima } \\
\mathrm{H} 4\end{array}$ & 2,02 \\
\hline
\end{tabular}

Berdasarkan perhitungan, nilai GoF index model penelitian sebesar 0,45 yang dapat diartikan bahwa model memiliki kekuatan prediksi kuat, karena nilai rule of thumb yang dikehendaki lebih besar 0,35 untuk dinyatakan kuat. Evaluasi model struktural juga didapatkan nilai koefisien jalur untuk menganalisis variabel yang potensial berpengaruh terhadap perilaku komplain. Penelian ini menggunakan nilai t hitung pada setiap variabel product quality, service quality, value and personality. Hipotesis dapat diterima jika nilai t hitung lebih dari 1,96 dan $p$ value < 0,05 (Latan \& Ghozali, 2012).

Hasil studi menemukan bahwa perceived product quality berpengaruh positif signifikan terhadap perilaku komplain. Berdasarkan Tabel 3 nilai t untuk product quality 2,05 yang menunjukkan nilai yang lebih besar dari 1,96 $(p=0,041)$. Hasil tersebut konsisten dengan penelitian sebelumnya dan mendukung hipotesis pertama dalam penelian ini bahwa perceived product quality memberikan pengaruh pada perilaku komplain konsumen. Hasil yang sama juga ditunjukkan variabel perceived service quality yang memberikan pengaruh positif signifikan terhadap perilaku komplain konsumen, dengan nilai t hitung 3,14 $(p=0,00)$. Hasil tersebut mendukung hipotesis ke-dua bahwa perceived service quality berpengaruh terhadap perilaku komplain. Untuk hipotesis ketiga perceived value memiliki pengaruh tidak signifikan terhadap perilaku komplain dengan nilai t hitung kurang dari 1,96 yaitu $0,57(p=0,57)$. Hipotesis keempat mengenai personality ditunjukkan dengan memiliki pengaruh signifikan terhadap perilaku komplain, dengan nilai $t$ hitung 2,02 $(p=0,04)$.

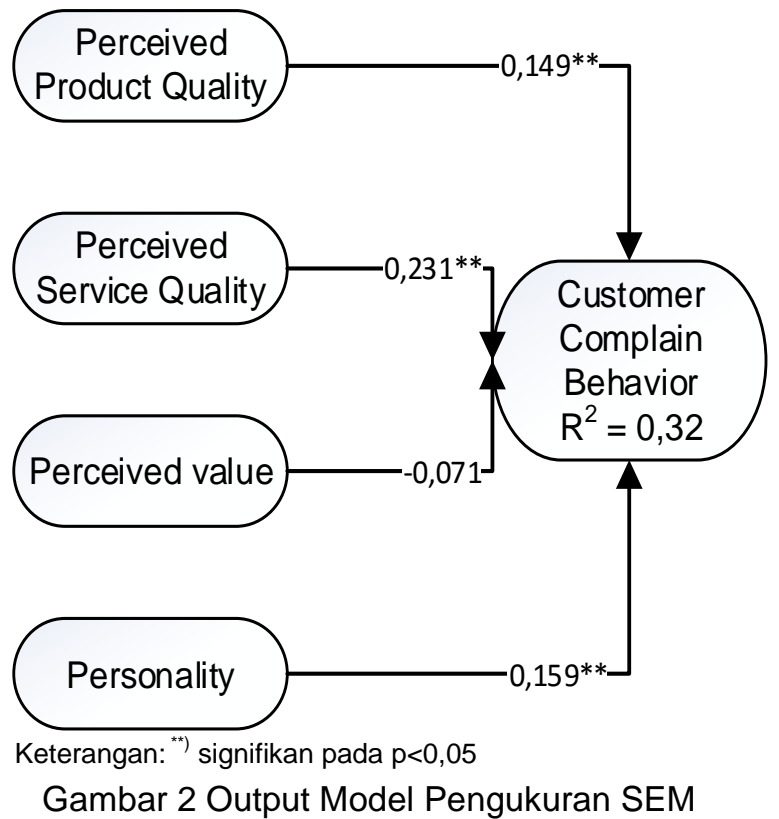

Hasil tersebut menunjukkan bahwa yang memiliki pengaruh terbesar dalam perilaku komplain terdapat pada perceived service quality. Hal ini mengindikasikan bahwa ketika kualitas layanan dari penjual maupun situs toko online lebih rendah dari harapannya maka kecenderungan konsumen untuk melakukan komplain akan semakin tinggi.

Untuk mendapatkan nilai pengujian hipotesis dan evaluasi struktur analisis yang dilakukan dalam penelitian ini adalah menggunakan SEM (Structural Equation Modelling). Empat Variabel yang digunakan yaitu perceived product quality, service quality, perceived value dan personality. Output model pengukuran dengan menggunakan SEM dapat dilihat pada gambar 2 .

\section{PEMBAHASAN}

Teori perilaku komplain terjadi akibat adanya kesalahan layanan atau produk yang diterima konsumen dan juga ketika persepsi yang diterima lebih rendah dari harapannya (Zeithmal, Bitner, \& Gremler, 2009). Hasil penelitian ini menunjukkan bahwa konsumen yang melakukan belanja online memberikan respon ketidakpuasan dengan melakukan komplain ketika mengonsumsi produk atau jasa dengan memerhatikan kualitas produk, layanan, nilai dan faktor personal. Hasil Penelitian ini Menemukan bahwa karakteristik konsumen memberikan kecenderungan berbeda dalam tipe komplain yang dilakukan. Pada mahasiswa perempuan yang berbelanja online, tipe komplain yang paling banyak dilakukan adalah voicer, hal ini menunjukkan bahwa perempuan lebih responsive terhadap 
kerusakan produk dan lebih sering meginformasikan kepada orang lain.

Hasil analisis menunjukkan bahwa variabel perceived product quality memiliki pengaruh secara langsung yang signifikan dan positif terhadap perilaku complain, salah satu indikatornya adalah kualitas produk yang diterima tidak memenuhi kebutuhan konsumen. Hal ini berarti semakin kualitas produk dipersepsikan buruk oleh konsumen pada produk online secara langsung akan meningkatkan perilaku komplain yang dilakukan oleh konsumen. Selain itu, kualitas workmanship dan durability produk yang diterima konsumen yang diberikan pelaku usaha belum dapat memenuhi kriteria kepuasan dari konsumen. Konsumen belanja online dalam penelitian ini masih menganggap produk online dari dua faktor tersebut masih tergolong rendah. Hasil penelitian ini juga sejalan dengan Donoghue dan Klerk (2006) dan juga Kim et al. (2014) yang menyebutkan atribut produk, sifat produk, dan kualitas produk berpengaruh terhadap perilaku komplain. Penelitian Jessie, Jihyun dan HsiaoLing (2017) menyatakan bahwa konsumen online akan memiliki tingkat kepuasan yang lebih tinggi akibat dari sifat produk yang tidak terlihat (tekstur bahan dan workmanship/kualitas pengerjaan). Perilaku komplain akibat ketidakpuasan produk direspon konsumen dengan tipe pengeluh voicer dengan mengeluh pada penjual dan tipe iratest atau komplain pada media sosial. Pengalaman ketidakpuasan yang disebabkan manufaktur produk cenderung melakukan komplain (Prasetya et al., 2016). Penelitian Cho, II, Roxanne, dan Jerry (2003) menemukan bahwa konsumen online cenderung lebih banyak mengeluh dalam kategori sensory product (baju, sepatu atau kosmetik). Studi juga menemukan konsumen yang membeli produk dengan harga yang rendah akan sedikit menunjukkan perilaku komplain (Kim et al., 2014) dan sebaliknya konsumen yang membeli produk yang mahal akan memiliki tingkat toleran yang lebih rendah dan lebih memilih komplain secara langsung kepada penjual (Prasetya et al., 2016; Fonseca, Sofia, \& Carlos, 2010).

Selanjutnya, hasil penelitian memperlihatkan bahwa perceived service quality secara langsung juga berpengaruh positif dan signifikan terhadap perilaku komplain. Temuan ini menunjukkan bahwa semakin kualitas layanan dipersepsikan buruk oleh konsumen akan meningkatkan komplain yang disampaikan oleh konsumen. Konsumen online cenderung lebih memerhatikan pelayanan dari penjual secara langsung, kompetensi dan pengetahuan penjual mengenai produk, dan jasa layanan toko. Beberapa hal tersebut belum dapat dipenuhi penjual online dan masih dianggap kurang oleh konsumen online pada penelitian ini. Hal ini sejalan dengan penelitian yang dilakukan Putri (2014) yang menemukan bahwa faktor yang memengaruhi ketidakpuasan pelanggan dan dapat menyebabkan komplain adalah variabel kualitas layanan dengan adanya karyawan yang kurang memiliki pengetahuan yang cukup terhadap produk yang ditawarkan. Cho et al. (2002) menyatakan kesalahan informasi dan respon yang lambat dari penjual mengakibatkan ketidakpuasan yang cukup tinggi dalam layanan online. Temuan ini juga sesuai dengan Velazquez et al. (2010) yang menyebutkan bahwa sistem informasi secara signifikan memengaruhi timbulnya intensitas perilaku komplain pelanggan. Jika perusahaan tidak berhasil menciptakan konsistensi produk atau jasa maka dapat menimbulkan persepsi yang buruk terhadap produk dan selanjutnya dapat memengaruhi sikap konsumen.

Penelitian ini juga menemukan bahwa kepribadian konsumen juga secara langsung berpengaruh positif signifikan terhadap perilaku komplain konsumen. Karakteristik personal konsumen menentukan tingkat toleransi kesalahan yang dilakukan oleh toko online (Cho et al., 2002). Personality extraversion memiliki tingkat toleransi yang lebih rendah dari karakteristik lain yakni openness to experience dan conscientiousness dikarenakan konsumen extraversion akan lebih menyampaikan yang dirasakan. Sesuai dengan Ekinci et al. (2016), karakteristik kepribadian yang dominan yang menggambarkan kepribadian konsumen dalam perilaku komplain adalah extraversion dan openness to experience, dengan negatif WOM dan permintaan kompensasi kepada penjual. Harris dan Mowen (2001) menyebutkan bahwa perilaku komplain konsumen dipengaruhi secara positif oleh karakteristik kepribadian extraversion. Phau dan Sari (2004) menyebutkan bahwa tipe pengeluh pada konsumen Indonesia cenderung akan mengambil resiko dan lebih positif terhadap komplain dan memiliki kepercayaan diri yang tinggi serta memiliki sifat yang individualis. Hasil studi ini bertentangan dengan Berry (2013) yang menyatakan kepribadian tidak signifikan terhadap perilaku komplain dan tidak signifikan terhadap menentukan saluran komplain yang digunakan. 


\section{SIMPULAN DAN SARAN}

Hasil penelitian menunjukkan bahwa alasan tidak puas mengenai belanja online disebabkan masalah produk cacat, delivery time, kesalahan pengiriman produk, penggantian produk tanpa konfirmasi dan produk tidak dikirim. Sementara ketidakpuasan mengenai layanan seperti pelayanan penjual, serta ketidaksesuain deskripsi dan tampilan. Kategori produk yang menyebabkan ketidakpuasan adalah kelompok produk fashion, kosmetik, dan elektonik. Penelitian ini menemukan bahwa perilaku komplain atas ketidakpuasan yang dirasakan konsumen belanja online ditunjukkan dengan empat tipe komplain yaitu passive, voicer, irates, dan jumlah paling kecil adalah activist. Konsumen online bertipe pengeluh (voice, irates) mempunyai proporsi terbesar pada konsumen perempuan, dengan uang saku tiap bulan di atas dua sampai empat juta rupiah, dan konsumen yang membeli produk dengan harga lebih tinggi. Variabel yang berpengaruh terhadap komplain adalah perceived product quality, perceived service quality, dan personality. Hasil menunjukkan bahwa semakin tinggi ketidakpuasan terhadap kualitas produk maka semakin tinggi tingkat komplain konsumen. Hal tersebut juga berlaku pada kualitas layanan belanja online. Sementara itu, untuk personality individu dengan tipe extraversion akan memiliki tingkat komplain yang semakin tinggi.

Berdasarkan penelitian ini mengenai perilaku komplain konsumen online, sebagai konsumen memegang peranan yang sangat penting dalam menjalin hubungan yang lebih baik dengan penjual online. Konsumen diharapkan memahami haknya sebagai konsumen bahwa menyampaikan komplain adalah merupakan upaya memberikan harapan pada perusahaan untuk memperbaiki kinerjanya. Salah satu cara yang tepat adalah dengan menyampaikan langsung kepada perusahaan maupun penjual yang bersangkutan mengenai masalah yang dialami. Konsumen dapat memanfaatkan layanan yang telah disediakan berupa layanan chatting dengan penjual secara langsung, menulis pada kolom komentar produk, maupun melalui website perusahaan. Konsumen juga dapat berperan aktif dalam memantau informasi pribadi yang berkaitan dengan toko online, sehingga konsumen diharapkan memerhatikan informasi terkait data pribadi yang tidak perlu dibagikan pada toko online.

\section{DAFTAR PUSTAKA}

[APJII] Asosiasi Penyelenggara Jasa Internet Indonesia. (2017). Survei asosiasi penyelenggara jasa internet Indonesia. Diakses 6 Agustus 2018. Tersedia pada http://www.apjii.or.od.

Aaker, D. A. (1997). Manajemen ekuitas merek, alih bahasa: Aris Ananda. Jakarta (ID): Spektrum Mitra Utama.

Ahn, T., Ryu, S., \& Han, I. (2004). The impact of the online and offline features on the user acceptance of Internet shopping malls. Electronic Commerce Research and Applications, 3(4), 405-420. doi:10.1016/j.elerap.2004.05.001.

Bayraktar, E., Tatoglu, E., Turkyilmaz, A., Delen, D., Zaim, S. (2012). Measuring the efficiency of customer satisfaction and loyalty for mobile phone brands with DEA. Expert Syst Appl, 39(1), 99-106.

Berry, R. A. (2013). How we complain: the effect of personality on customer complaint channels (Tesis). University of Nevada, Las vegas, United State.

Cao, Y., Haya, A., \& Paul, H. (2017). Postpurchase shipping and customer service experiences in online shopping and their impact on customer satisfaction: an empirical study with comparison. Asia Pacific Journal of Marketing and Logistics, 30(2), 400-416. doi: 10.1108/APJML-042017-0071.

Cho, Y., II, Im., Roxanne, H., \& Jerry, F. (2003). The impact of product category on customer dissatisfaction in cyberspace. Business Process Management Journal, 9(5), 635-651.

Cho, Y., II, Im., Roxanne, H., \& Jerry, F. (2002). The effects of postpurchase evaluation factors on online vs offline customer complaining behavior: implication for customer loyalty in NA. Advances in Customer Research, 29: 318-326.

Crie, D. (2003). Consumers compliant behaviour taxonomy, typology and determinants: towards a unified ontology. Database Marketing \& Customer Strategy Management, 11(1), 60-79.

Donoghue, S., \& Klerk, H. M. (2006). Dissatisfied customer complaint behaviour concerning product failure of major electrical household appliances-a conceptual framework. Journal of Family 
Ecology and Consumer Sciences, 34, 4155.

Daily socialid. (2016). Laporan customer satisfaction in indonesia's e-commerce service tahun 2016, Diakses 2 Juli 2018. Tersedia pada http://www.dailysocial.id.

Davidow, M. (2000). The bottom line impact of organizational responses to customer complaints. Jurnal of Hospitality \& Tourism Research, 24(4), 473-490, doi $: 10.1177 / 109634800002400404$.

Ekinci, Y., Calderon, J., \& Siala, H. (2016). Do personality trait predict complaining customer?. Journal of Business Environment, 8(1), 32-42.

Fonseca, F., Sofia, P., Carlos, B. (2010). Service quality and customer satisfaction in public transports. International Journal for Quality research, 4(2), 125-130.

Hair, R., Black, W., Babin, B., Anderson, R., Tarham, R. (2006). Multivariate data analysis Ed $5^{\text {th }}$. New Jersey, NJ: Pearson Prentice hall.

Halstead, D., \& Droge, C. (1991). Customer attitudes toward complaining and the prediction of multiple complaint responses. Advances in Consumer Research, 18(1), 210-216.

Harris, E.G., \& Mowen, J. C. (2001). The influence of cardinal central and surface level personality traits on consumers bargaining and complaint intentions. Psychology \& Marketing, 18(11), 11551185.

Hwang, J., \& Zhao, J. (2010). Factors influencing customer satisfaction or dissatisfaction in the restaurant business using answer tree methodology. Journal of Quality Assurance in Hospitality \& Tourism, 11(2), 93-11. doi: 10.1080/15280081003800355.

Jessie, C. Y., Jihyun, Kim., \& Hsiao-Ling, L. (2017). Antecedents of product satisfaction and brand satisfaction at product receipt in an online apparel shopping context. Journal of Global Fashion Marketing, 8(3), 207-219. doi: 10.1080/20932685.2017.1298460.

Kim, M. G., Lee, C. H., \& Mattila, A. S. (2014). Determinants of customer complaint behavior in restaurant context: The role of culture, price level, and customer loyalty. Journal of hospital marketing and management, 23(8), 885-906. doi.org/10.1080/19368623.2014.896762.
Kim, J., \& Boo, S. (2011). Influencing factors on customer intention to complaint in a franchise restaurant. Journal of Hospitality Marketing \& Management, 20(2), 217237. doi.10.1080/19368623.2010.514559.

Kotler \& Keller. (2009). Manajemen Pemasaran Jilid I edisi 13. Jakarta (ID): Erlangga.

Krisno, D., \& Samuel, H. (2013). Pengaruh perceived quality, perceived sacrifice dan perceived value terhadap customer satisfaction di Informa innovative furnishing Pakuwon City Surabaya. Jurnal Manajemen Pemasaran Petra, 1(1), 1-12.

Latan, H., \& Ghozali, I. (2012). Partial least squares, konsep, teknik, dan aplikasi SmartPLS 2.0 M3 untuk penelitian empiris. Semarang (ID): Universitas Diponegoro.

Malik, S. (2012). Customer satisfaction, perceived quality and mediating role of perceived value. International Journal of Marketing studies, 4(1), 68-76.

Ndubisi, N. O., \& Ling, T. Y. (2006). Complaint behaviour of Malaysian customers. Management research News, 29(1/2), 6576. doi.10.1108/01409170610645457.

Phau, I., \& Sari, R. P. (2004). Engaging in complait behavior: an Indonesian perspective. Marketing Intelligence \& Palnning, 22(4), 407-426.

Putri, C. P. (2014). Analisis faktor-faktor yang mempengaruhi komplain pelanggan pada educotourism "kampung jamu jeng ratu Indonesia (Tesis). Institut Pertanian Bogor, Bogor, Indonesia.

Prasetya, A., Hartoyo., \& Tinaprila, N. (2016). Behavior analysis of consumer complaint. Indonesian Journal of Business and Entrepreneurship, 2(2), 101-111, doi: 10.17358/IJBE.2.2.101.

Quareshi, G. K. T. (2015). Factors obstructing intentions to trust and purchase products online. Asia Pacific Journal of Marketing and Logistics, 27(5), 758-783. doi: 10.1108/APJML-10-20140146.

Ramadhani, H. S. (2014). Pengaruh product quality, service quality dan perceived value terhadap kepuasan dan loyalitas konsumen SOP durian XYZ. (Tesis). Institut Pertanian Bogor, Bogor, Indonesia.

Shafiee, M. M., \& Bazargan, N A. (2017). Behavioral customer loyalty in online 
shopping: the role of e-service quality and e-recovery. Journal of theoretical and applied electronic commerce research, 13(1), 27-38.

Shergil, G. S., \& Chen, Z. (2005). Web-based shopping: consumers' attitudes towards online shopping in New Zealand. Journal of Electronic Commerce Research, 6(2), 78-94.

Simanjuntak, M., \& Hamimi, U. K. 2019. Penanganan komplain dan komunikasi Word-Of-Mouth (WOM). Jurnal IImu Keluarga dan Konsumen, 12(1), 75-86. http://dx.doi.org/10.24156/jikk.2019.12.1.7 5.

Sweeney, J. C., \& Soutar, G. N. (2001). Consumer perceived value: the development of a multiple item scale. Journal of Retailing, (77), 203-220.
Thogersen, J., Juhl, H. J., \& Poulsen, C. S. (2009). Complaining: a function of attitude, personality, and situation. Psychology \& Marketing, 26(8), 760-77. doi: 10.1002/mar.20298.

Tronvoll, B. (2008). Customer complaint behavior in service (Disertasi). Karlstad University Studies, Karlstad, Swedia.

Velazquez, B. M., Blasco, M. F., Saura, I. G., Contri, G. B. (2010). Cause for complaining behaviour intention: the moderator effect of previous customer experience of the restaurat. Journal of Services Marketing, 24(7), 532-545.

Zeithaml, V. A., Bitner, M. J., \& Gremler, D. D. (2009). Service marketing $5^{\text {th }}$ edition. New York (US): Mc-Graw Hill. 